Research Article

\title{
Cytotoxic and Antimigration Activity of Etlingera alba (A.D.) Poulsen Rhizome
}

\author{
W. Wahyuni $\mathbb{D}^{1,2}$ Ajeng Diantini ${ }^{1}{ }^{1},{ }^{1}$ Mohammad Ghozali $\mathbb{D}^{\circ},{ }^{3}$ Anas Subarnas $\mathbb{D}^{1},{ }^{1}$ \\ Euis Julaeha $\mathbb{D}^{4},{ }^{4}$ Riezki Amalia $\mathbb{D}^{1},{ }^{1}$ and I. Sahidin $\mathbb{D}^{2}$ \\ ${ }^{1}$ Department of Pharmacology and Clinical Pharmacy, Faculty of Pharmacy, Universitas Padjadjaran, Jatinangor, Indonesia \\ ${ }^{2}$ Faculty of Pharmacy, Universitas Halu Oleo, Kendari, Indonesia \\ ${ }^{3}$ Department of Biomedical Sciences, Faculty of Medicine, Universitas Padjadjaran, Jatinangor, Indonesia \\ ${ }^{4}$ Department of Chemistry, Faculty of Mathematics and Natural Sciences, Universitas Padjadjaran, Jatinangor, Indonesia
}

Correspondence should be addressed to Ajeng Diantini; diantini.ajeng@gmail.com

Received 28 July 2021; Revised 13 October 2021; Accepted 16 November 2021; Published 28 December 2021

Academic Editor: Heng Yen Khong

Copyright ( $\odot 2021 \mathrm{~W}$. Wahyuni et al. This is an open access article distributed under the Creative Commons Attribution License, which permits unrestricted use, distribution, and reproduction in any medium, provided the original work is properly cited.

Etlingera alba is one of the Etlingera plants that might have anticancer activity. This study aims to investigate the cytotoxic and antimetastatic activity of $E$. alba rhizome fractions and migration cell assay against MDA-MB-231 cell lines, which are used for triple-negative breast cancer (TNBC) treatment assay. The cytotoxic activity was assayed using CCK- 8 assay, while the antimetastatic was assayed using migration cell assay for the fractions A-F. They were followed by LCMS/MS profiling to determine the chemical contents in the most active fraction. According to results obtained, fraction $\mathrm{B}$ was the most active fraction for cytotoxic activity with an $\mathrm{IC}_{50}$ value of $65.43 \mu \mathrm{g} / \mathrm{mL}$, while fraction $E$ was the most active fraction for antimetastasis activity against migration rate doses of 50,100, and $200 \mathrm{ppm}$ which were $6.80,3.66$, and $3.00 \%$, respectively. Several compounds in fraction B, such as rengyolone, licochalcone A, sugiol, and spinasterol, might have been known to have activity against cancer cells, as well as aschantin and lirioresinol B dimethyl ether from fraction E. In conclusion, the chemical components from E. alba rhizome fractions provided potency for discovering new agents for cancer treatment, specifically for TNBC.

\section{Introduction}

Cancer is the first or second leading cause of death, mainly worldwide, according to WHO (World Health Organization). The incidence and mortality gradually increase each year, including breast cancer. In 2020, the new cases and deaths reported were 2.261 .419 cases $(11.7 \%)$ and 684.999 deaths $(6.9 \%)$ because of breast cancer [1]. Breast cancer is commonly metastatic cancer, thus it can transfer to other organs and cause death [2].

Triple-negative breast cancer (TNBC) is a kind of breast cancer diagnosed in 15-20\% of breast cancer cases. It is categorized with lack or absence of the presence of estrogen (ER), progesterone (PR), and HER-2 (human epidermal growth receptor-2) receptor expression. The TNBC contributes to 170,000 cases with more aggressive behavior, high risk of recurrence, and high mortality than the non-TNBC [3-6].
In treating breast cancer, surgery, radiation therapy, and chemotherapy are the options. The chemotherapy is administered to shrink the tumor before the surgery. However, they can cause many side effects, such as nausea and vomiting, neutropenia, rash and redness, nephrotoxicity, and cardiotoxicity[7]. Therefore, discovering a new agent with the lowest side effect and high efficacy is required because the TNBC has poor prognosis than other breast cancer types. Many compounds from terrestrial plants are the potential for providing anticancer activity. For example, chemotherapy agents such as taxol, vincristine, and vinblastine are from terrestrial plants $[6,8,9]$.

Etlingera alba (A.D.) Poulsen is one of the newest Etlingera species found in Southeast Sulawesi, and not many studies are conducted on it. The E. alba is well known medicinal herb similar to E. elatior, mainly used to treat wounds, as deodorant, and as earache medicine. A previous 
study showed that E. alba rhizome extract has antibacterial and anti-inflammatory properties [10,11]. E. alba becomes a promising candidate as a source of therapeutical agents. Many studies showed that species that belong to similar genus provide similar activities. For example, E. elatior is a species that belongs to a similar genus with $E$. alba. It provides antibacterial, antioxidant, anti-inflammatory, and antipyretic properties. Secondary metabolites, including phenolics, alkaloids, flavonoids, steroids, saponin, and volatile oil, are responsible for providing these properties [11].

E. elatior flower provides cytotoxic activity against MDA-MB-231 cell line with $\mathrm{IC}_{50} 196.2 \mu \mathrm{g} / \mathrm{mL}$ [12], E. belalongensis rhizome and stem with $\mathrm{IC}_{50} 51.00 \pm 4.24$ and $74.00 \pm 2.83 \mu \mathrm{g} / \mathrm{mL}$, respectively [13], and E. velutina rhizome and stem with $\mathrm{IC}_{50} 67.00 \pm 9.89$ and $89.50 \pm 14.85 \mu \mathrm{g} /$ $\mathrm{mL}$, respectively [13]. In addition, bioactive compound trans-4-methoxycinnamaldehyde (4-MCA) identified in E. pavieana rhizome exhibited IC50 values $39.33 \pm 1.53 \mu \mathrm{g} /$ $\mathrm{mL}$ against MDA-MB-231 cell lines [14]. MDA-MB-231 cell is an invasive ductal/breast carcinoma cell which is one of the tools for researching TNBC because it lacks amplifying estrogen receptor (ER) and progesterone receptor (PR) expression, as well as HER2 (human epidermal growth factor receptor 2). It is highly metastatic and aggressive $[15,16]$. Thus, we aim to investigate the cytotoxic activity of fractions from extract $E$. alba rhizomes by using CCK-8 assay against MDA-MB-231 cell lines and their metastatic activity by using migration cell assay.

\section{Materials and Methods}

2.1. Plant Material. Etlingera alba rhizomes were obtained from Punggaluku of South Konawe Regency in Southeast Sulawesi (4019'26"S $\left.122028^{\prime} 58^{\prime \prime} \mathrm{E}, 325 \mathrm{~m}\right)$. The rhizomes were dried at $40^{\circ} \mathrm{C}$ and direct sunlight was avoided. The rhizomes were powdered and stored in a sealed jar for further analysis.

2.1.1. Cell Lines Preparation and Culture. MDA-MB-231 cell line was grown in $100 \mathrm{~mm}$ plate in $\mathrm{CO}_{2}$ incubator and observed under an inverted microscope. The cell line was seeded in 6-well plates with $2 \mathrm{~mL}$ of media per well. A total of $2 \times 10^{4}$ cells/well were needed for cytotoxicity assay and migration assay using scratch wound-healing assay. Cell distribution was observed under an inverted microscope to obtain the even distribution until attaining $\sim 70-80 \%$ of confluence.

2.2. Chemical Reagents. Ethanol $95 \%$ (technical grade), silica gel $60(0.063-0.200 \mathrm{~mm})$ Merck 107734, silica gel 60 GF254 Merck 1.07730, TLC silica gel $60 \mathrm{~F}_{254}$ Merck 1.05554.0001, n-hexan (technical grade), ethyl acetate (technical grade), methanol (technical grade), formic acid, water, acetonitrile, Dulbecco's modified Eagle medium (DMEM)-high glucose (Sigma); fetal bovine serum (Sigma); trypsin TrypLE (Gibco); penicillin-streptomycin (Sigma); phosphate buffer saline 10X (Lonza); cell counting kit-8 (product code: CK04).
2.3. Apparatus. Vacuum rotary evaporator $\left(\mathrm{Buchi}^{\circledR}\right)$, vacuum liquid chromatography (VLC), LCMS/MS, Xevo G2-XS QTOF (Waters Corporation, Milford, USA), microplate reader, 96-well microplate; 6-well plate (Nest); plate $100 \mathrm{~mm}$ (Nest); serological pipettes $5 \mathrm{~mL}, 10 \mathrm{~mL}$, and $25 \mathrm{~mL}$ (Nest); micropipette (Eppendorf) in various measurements, pipette tips in $1000 \mu \mathrm{L}$ (GenFollower), $200 \mu \mathrm{L}$ (GenFollower), and $10 \mu \mathrm{L}$ (Biologix); $\mathrm{CO}_{2}$ incubator (Thermo Scientific); centrifuge tubes $15 \mathrm{~mL}$ and $50 \mathrm{~mL}$ (Nest); haemocytometer (Assistant-Germany); light microscope Axio Vert.A.1 (Zeiss) camera build-in, and Zen microscope software (Zeiss); biological safety cabinet-level II (ESCO); centrifuge PLC series; Multi-Vortex V-32 (Biosan).

2.4. Extraction and Fractionation. A total of $5.5 \mathrm{~kg}$ of powdered E. alba rhizome was macerated with $96 \%$ ethanol for $3 \times 24 \mathrm{hrs}$ at room temperature. The filtrate obtained was concentrated under a low-pressure vacuum with a rotary evaporator at $40^{\circ} \mathrm{C}$ in $160 \mathrm{~g}$ of concentrated extract $(2.9 \%)$. The extract was impregnated into silica gel and fractionated using vacuum liquid chromatography $(\mathrm{VLC}, 10 \times 5 \mathrm{~cm})$ and the mixture of $n$-hexane: ethyl acetate with increased polarity $(9: 1$ to $0: 10 \mathrm{v} / \mathrm{v})$ and pure $\mathrm{MeOH}$ till obtained 6 fractions. The fractions were fraction A $(3,239 \mathrm{~g})$; fraction $\mathrm{B}$ (4,345 g); fraction C (5,362 g); fraction $D(1,563 \mathrm{mg})$; fraction $E(4,432 \mathrm{mg})$; and fraction $F(74,224 \mathrm{mg})$.

2.5. Cytotoxic Assay. The triple-negative breast cancer cell line (MDA-MB-231) was obtained from the collection of the Department of Pharmacology and Clinical Pharmacy, Universitas Padjadjaran. The cells were grown in Dulbecco's modified Eagle medium (Sigma-Aldrich, St. Louis, MO) containing 10\% fetal bovine serum (Sigma-Aldrich, St. Louis, MO) and 1\% penicillin-streptomycin (Sigma-Aldrich, St. Louis, MO). The cell line was seeded in a 96-well plate and cultured for $24 \mathrm{~h}$ at $37^{\circ} \mathrm{Chrs}$ in a humidified atmosphere of $5 \% \mathrm{CO}_{2}$. The cells were refreshed with new media and treated with various concentrations of samples, cisplatin was used as control, and DMSO was used as blank. After $24 \mathrm{~h}$, cell counting kit-8 (CCK) reagent (Dojindo, Rockville, MD, USA) was added, and the mixtures were incubated for $4 \mathrm{~h}$. The absorbances were measured using a Tecan Infinite spectrophotometer $(\lambda 450 \mathrm{~nm})$.

2.6. Migration Cell Assay. The migration rates of MDA-MB231 cells were assessed by the scratch assay method. The cells were seeded in 6-well plates, and after $70-80 \%$ confluency, the media was replaced with a low FBS growth medium (concentration $0.5 \%$ ) and cultured at $37^{\circ} \mathrm{C}$ in a humidified atmosphere of $5 \% \mathrm{CO}_{2}$. After $24 \mathrm{~h}$, the monolayer cells were scratched with sterile yellow micropipette tips, and the cells' debris was washed with PBS. The cells were treated with various concentrations of a sample by diluting with serumfree DMEM. The cells treated with cisplatin were used as a positive control. The scratch induced that represented wound was photographed at $0 \mathrm{~h}$ using phase-contrast microscopy at $\times 40$ magnification at $0 \mathrm{~h}$. After $24 \mathrm{~h}$ of 
incubation, the second set of images was photographed, and the percentage of the closed area was measured and compared with the value obtained at $0 \mathrm{~h}$. An increase in the percentage of the closed area indicated the migration of cells.
Experiments were performed in a triplicate manner, and the data were recorded and analyzed statistically using SPSS.

To determine the migration rate, the migration percentage (\%) was calculated as

$$
\% \text { migration }=\frac{(\text { diameter at } 0-\mathrm{hrs})-(\text { diameter at } 24-\mathrm{hrs})}{(\text { diameter at } 0-\mathrm{hrs})]} \times 100 \%
$$

2.7. LCMS/MS. Fraction $\mathrm{B}$ and $E$ were identified chemically using LCMS/MS analysis, Xevo G2-XS QTOF (Waters Corporation, Milford, USA), equipped with an electrospray ionization source (ESI). The HSS T3 C18 column was reversed phase $(2.1 \times 100 \mathrm{~mm}$, particle size $1.8 \mathrm{~m})$ at $40^{\circ} \mathrm{C}$. The mobile phase consisted of A ( $0.1 \%$ formic acid in water) and $\mathrm{B}$ (acetonitrile in $0.1 \%$ formic acid). Elution gradient was at a flow rate of $0.3 \mathrm{~mL} / \mathrm{min}$ with an injection volume of $1 \mathrm{~L}$. The gradients were $5 \% \mathrm{~B}(0-8 \mathrm{~min}), 40 \% \mathrm{~B}(8-11 \mathrm{~min})$, and $100 \%$ B (11-16 min). Data range from $50-1200 \mathrm{~m} / \mathrm{z}$. The applied source temperature was $120^{\circ} \mathrm{C}$, and the desolvation gas flow was $1000 \mathrm{~L} /$ hour with a desolvation temperature of $500^{\circ} \mathrm{C}$. The capillary voltage was at $2.0 \mathrm{kV}$, and the cone voltage was $30 \mathrm{~V}$. Low energy scan was at $6.00 \mathrm{eV}$ and high energy scan at $40 \mathrm{eV}$. All LCMS data were processed, peaked, and analyzed. The variables of interest were then identified using the UNIFI software.

\section{Results and Discussion}

The inhibition of each fraction against MDA-MB-231 cells exhibited various activities. The chemical compounds in each fraction influence these results. Each chemical compound will have a molecular structure with specific physical and chemical properties. The different properties of each of these molecular structures, of course, provide different pharmacological effects. According to Figure 1, the extract and fractions exhibited concentration-dependent inhibition with the higher concentration which gave higher inhibition activity. Fraction B provides better inhibitory activity similar to cisplatin than another fraction against MDA-MB-231 cell line with an $\mathrm{IC}_{50}$ value of $65.43 \mu \mathrm{g} / \mathrm{mL}$ closest to cisplatin with an $\mathrm{IC}_{50}$ value of $53.37 \mu \mathrm{g} / \mathrm{mL}$. The $\mathrm{IC}_{50}$ values of extract, fraction $\mathrm{A}$, fraction $\mathrm{C}$, fraction $\mathrm{D}$, fraction $\mathrm{E}$, and fraction $\mathrm{F}$ were $453.36 ; 252.25 ; 497.98 ; 262.5 ; 345.3$; and $1840.85 \mu \mathrm{g} /$ $\mathrm{mL}$.

Analog to Figure 2, cisplatin is used as control due to its ability to disrupt the cell division and trigger cell death by forming cross-links with guanine bases of DNA double helix chain leading to transcription and DNA replication interfered. Like cisplatin, the chemical compounds contained in fraction B certainly have an essential role in cytotoxic effects on MDA-MB-231 cells.

Migration is a critical event in cancer progression, specifically in metastasis; thus, the extract of E. alba rhizome and its fractions were evaluated [17]. The cell migration rate is shown in Figure 3, in which cells migrate towards the provisional induced in 24 hours [18]. Figure 4 shows that cells migrate in $24 \mathrm{hrs}$. The study results demonstrated that fraction $\mathrm{E}$ showed the lowest migration rate compared to other fractions and the extract itself by the concentrations 50,100 , and $200 \mathrm{ppm}$ in a dose-dependent manner, which were $6.80,3.66$, and $3.00 \%$. They were not significant to cisplatin as control, which was $5.66,4.84$, and $1.61 \%$, respectively. It suggests that fraction $\mathrm{E}$ can prevent the metastasis that produces secondary tumors in an organism [19].

A previous study showed that cisplatin could prevent metastasis by blocking the early step of EMT (epithelialmesenchymal transition). Cisplatin blocks the cell migration induced by transforming growth factor-beta (TGF- $\beta$ ), which acts as a tumor promoter that leads to metastasis. On MDAMB-231 cells, cisplatin blocks the filopodia formation associated with dynamic cytoskeleton rearrangement induced by TGF- $\beta$ cells during cell movement [20]. The fraction F provides similar activity to control, which is cisplatin observed $12 \mathrm{hr}$ after treatment. The mechanism itself is similar to cisplatin by blocking the filopodia formation in cell movement.

Analysis of the chemical content in fractions B and $\mathrm{E}$ using LCMS/MS showed separated compounds based on their polarity. The initial compounds that appear first are polar and are increasingly nonpolar as the retention time on the chromatogram increases [21]. The chromatogram at each retention time (Figures 5(a) and 5(b)) obtained was processed using UNIFI software so that peak height, area, and fragmentation spectra of chemical compounds could be known so that the formula and molecular structure of the compound could be understood. Each chromatogram peak induces one chemical compound. The results obtained in the LCMS/MS analysis are presented in Table 1, while the chemical compounds' structure is shown in Figures 6 and 7, respectively.

LCMS-MS profiling of fraction $B$ and fraction $E$ is shown in Figures 5(a) and 5(b), in which retention time (Rt) was observed from 5.99 to 11.69 min for fraction B and 1.38 to 9.28 min for fraction E. For fraction B (Table 1), compound 1 in positive mode ions appeared at time 5.99 min with peak $[\mathrm{M}+\mathrm{Na}]^{+}$at $\mathrm{m} / \mathrm{z} 153.0534$, with mass 130 which confirmed it was 3-hydroxy-2,5-hexadione with formula $\mathrm{C}_{6} \mathrm{H}_{10} \mathrm{O}_{3}$. This process can be applied to determine the other compounds seen in Tables 1 and 2, respectively, for fractions B and E. The structure of each compound is available in Figures 6 and 7, respectively.

Although each fraction contains such compounds, not all of them provide anticancer activity. Sometimes they even synergize with each other to provide this activity. Several 


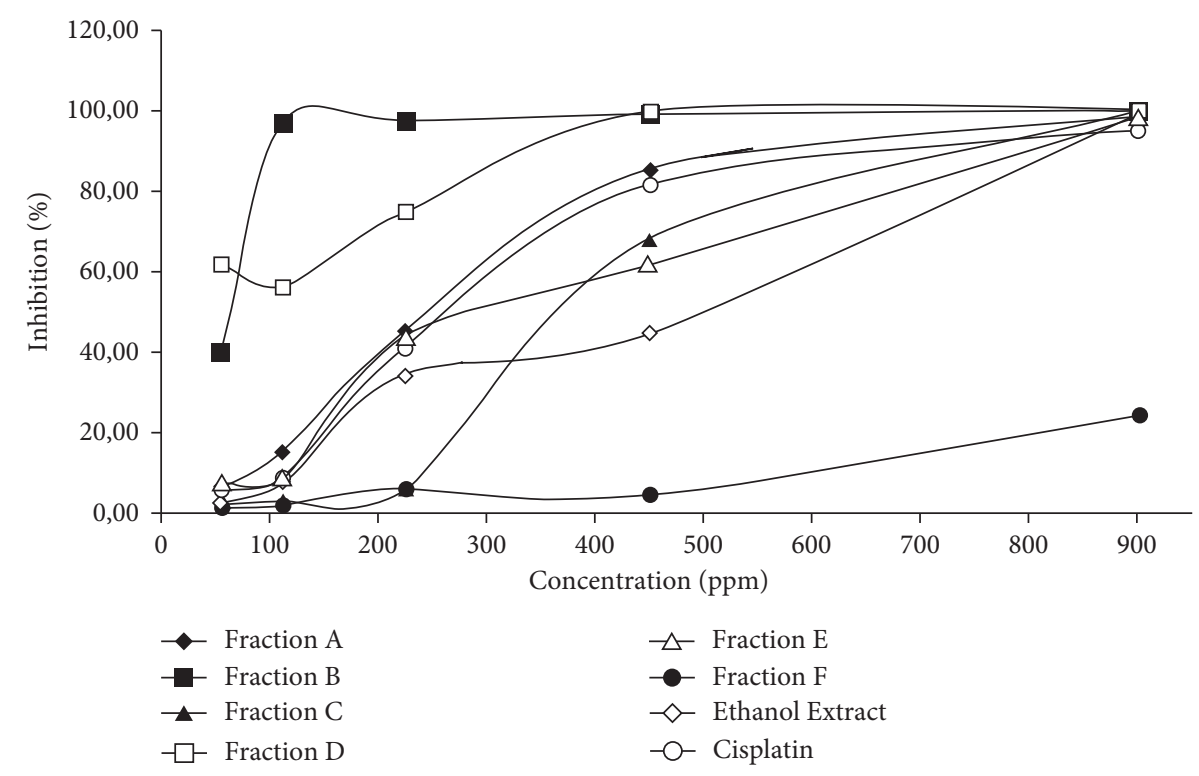

FIGURE 1: Inhibitory activity of extract and fractions on MDA-MB-231 cell line growth in various concentrations.

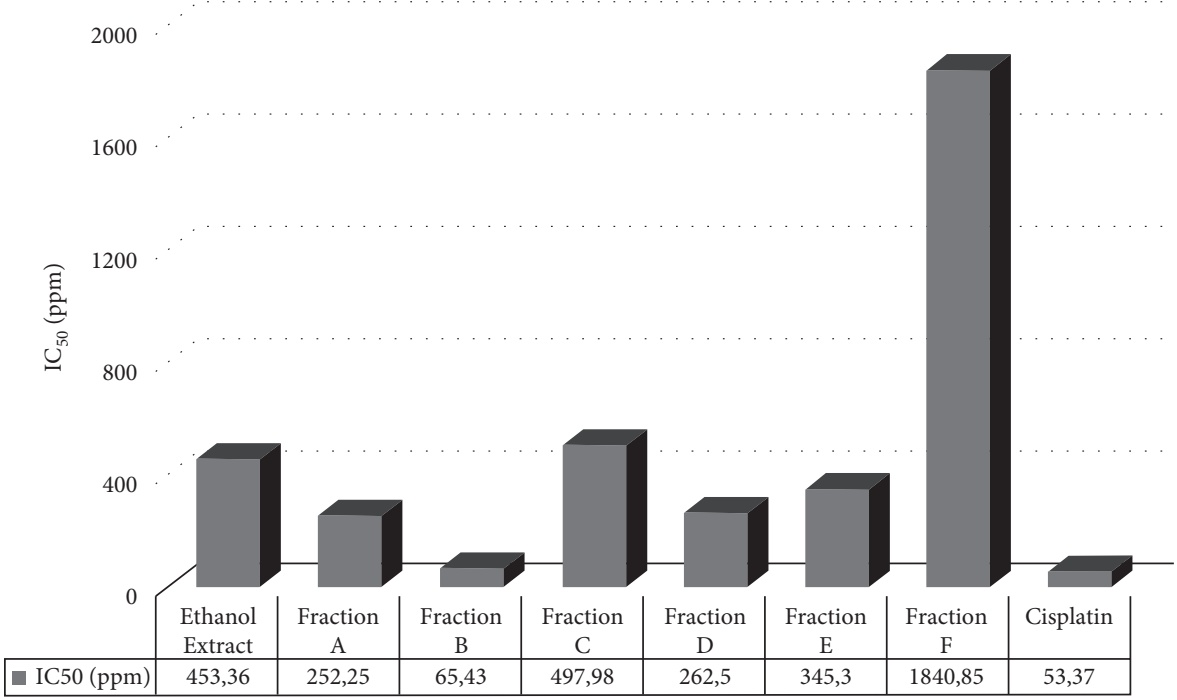

Figure 2: $\mathrm{IC}_{50}$ value of extract and fraction on MDA-MB-231 cell growth.

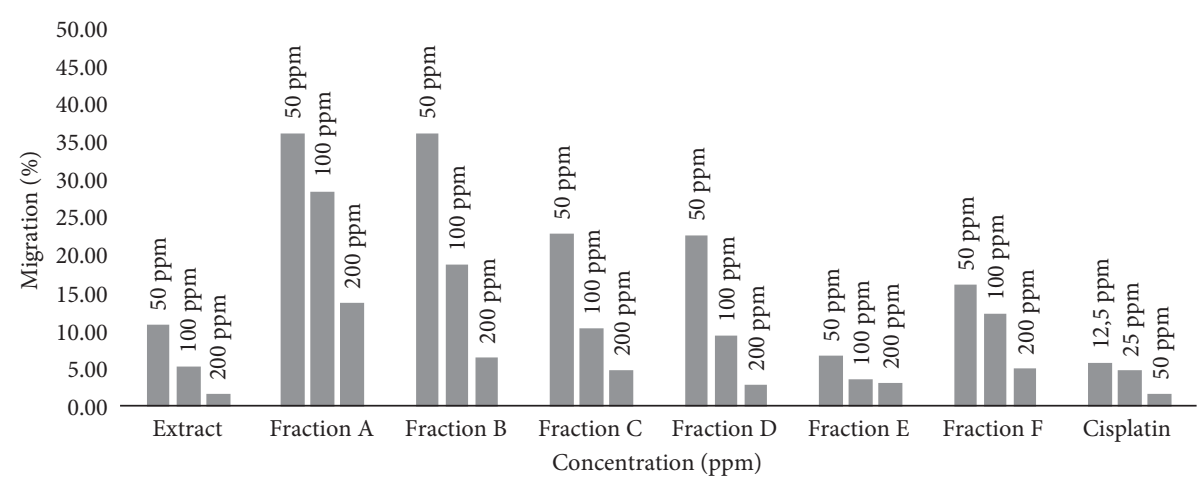

FIGURE 3: The migration rate in percentage for MDA-MB-231 cell line. 
$0 \mathrm{~h}$

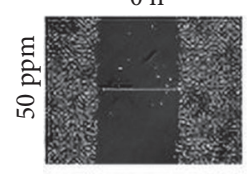

蒁
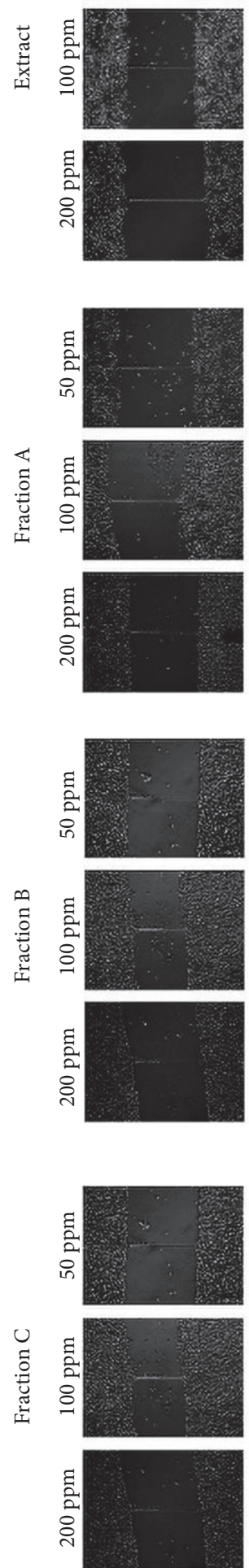

$24 \mathrm{~h}$
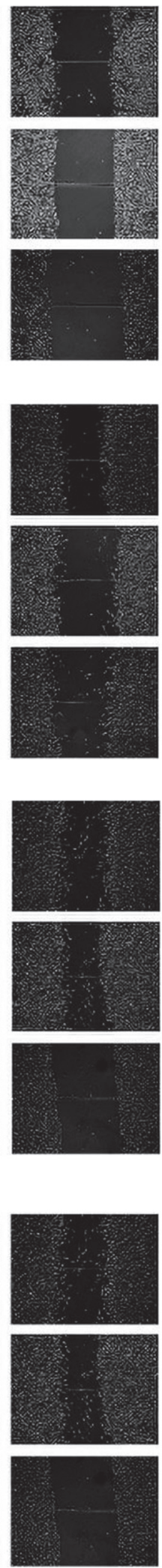

$0 \mathrm{~h}$
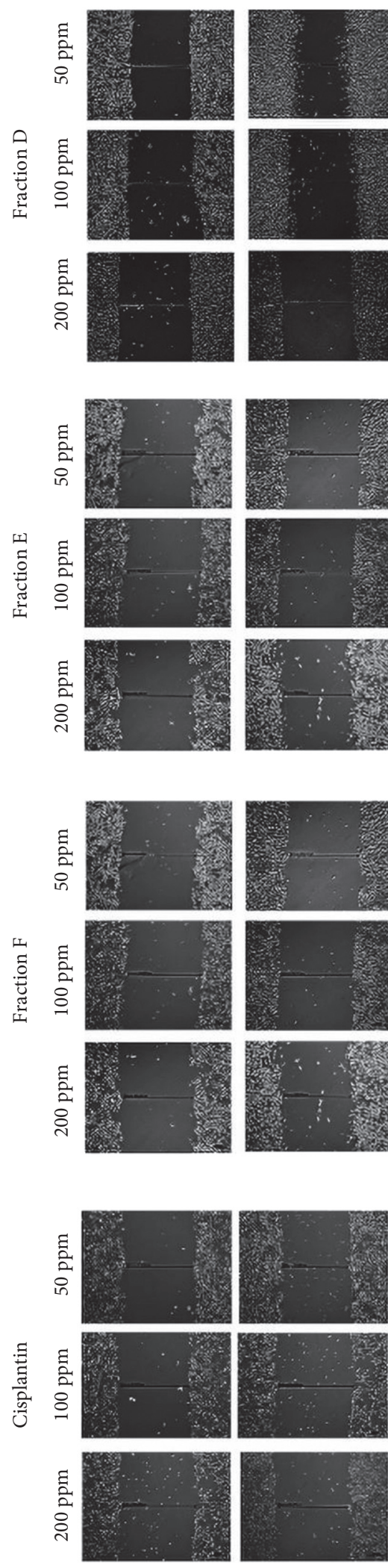

$24 \mathrm{~h}$
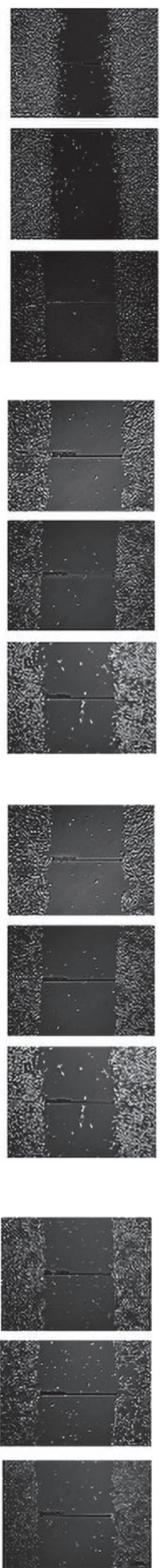

FIGURE 4: In vitro scratch assay ( $\times 40$ magnification) of MDA-MB-231 cells towards extract, fractions, and cisplatin in various concentrations (50 ppm; 100 ppm; and $200 \mathrm{ppm}$ ). 


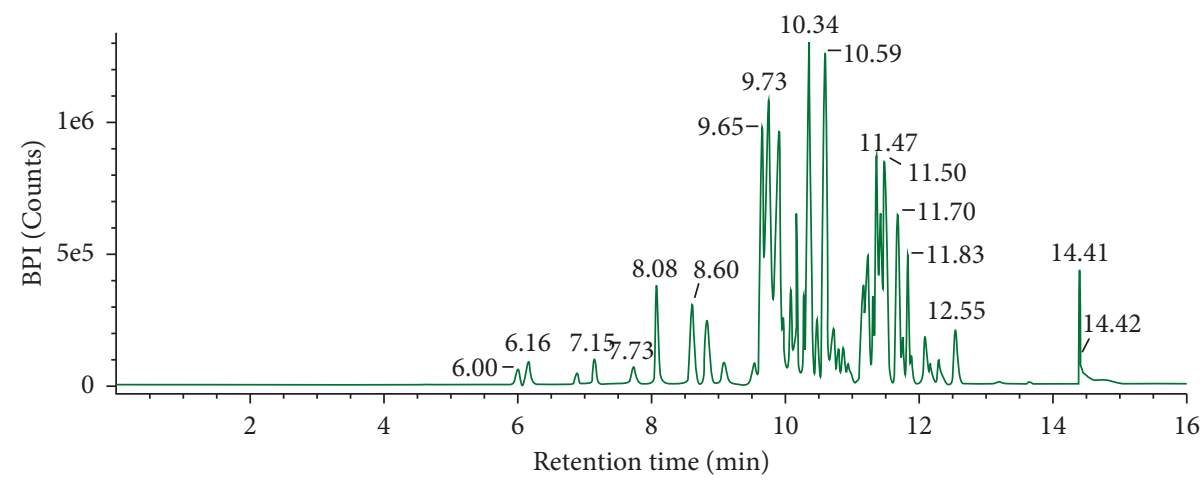

(a)

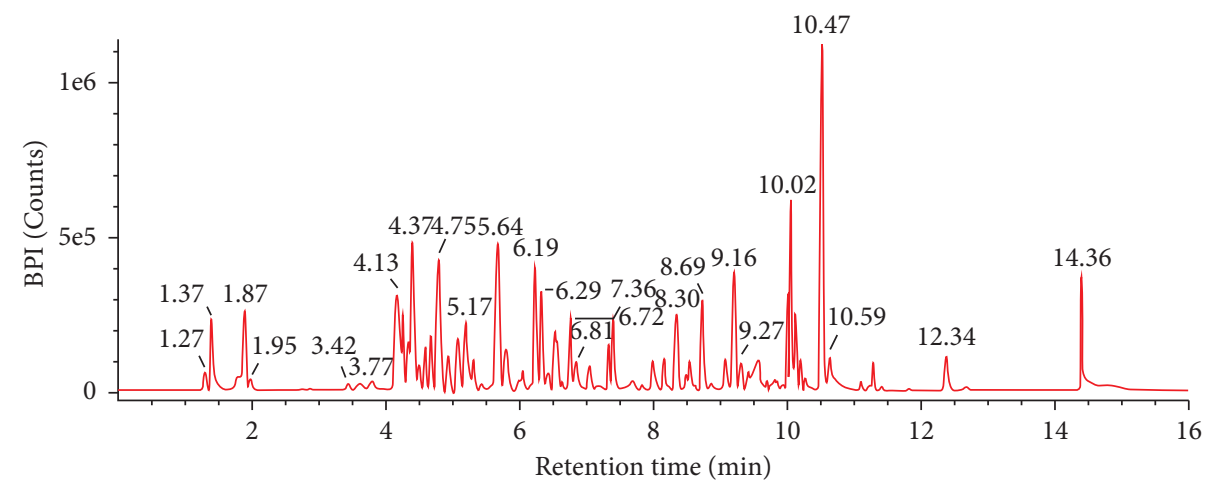

(b)

FIGURE 5: LCMS chromatogram of the chemical constituents of fraction B (a) and fraction E (b).

TABle 1: Chemical composition of fraction B.

\begin{tabular}{lccccc}
\hline No. & Observed Rt $(\mathrm{min})$ & Observed $(\mathrm{m} / \mathrm{z})[(+)$-ESI $]$ & Neutral mass $(\mathrm{Da})$ & Formula & Compound name \\
\hline 1 & 5.99 & $153.0534[\mathrm{M}+\mathrm{Na}]^{+}$ & 130.06299 & $\mathrm{C}_{6} \mathrm{H}_{10} \mathrm{O}_{3}$ & $\begin{array}{c}\text { 3-Hydroxy-2,5-hexadione } \\
2\end{array}$ \\
6.16 & $183.0640[\mathrm{M}+\mathrm{H}]^{+}$ & 182.05791 & $\mathrm{C}_{9} \mathrm{H}_{10} \mathrm{O}_{4}$ & Methyl-3-hydroxy-4-methoxybenzoate \\
3 & 7.15 & $155.0690[\mathrm{M}+\mathrm{H}]^{+}$ & 154.06299 & $\mathrm{C}_{8} \mathrm{H}_{10} \mathrm{O}_{3}$ & Rengyolone \\
4 & 8.08 & $216.1736[\mathrm{M}+\mathrm{H}]^{+}$ & 215.16740 & $\mathrm{C}_{15} \mathrm{H}_{21} \mathrm{~N}$ & Candidate mass $\mathrm{C}_{15} \mathrm{H}_{21} \mathrm{~N}$ \\
5 & 8.61 & $179.0691[\mathrm{M}+\mathrm{H}]^{+}$ & 178.06299 & $\mathrm{C}_{10} \mathrm{H}_{10} \mathrm{O}_{3}$ & tran-Ferulaldehyde \\
6 & 9.66 & $195.1004[\mathrm{M}+\mathrm{H}]^{+}$ & 194.09429 & $\mathrm{C}_{11} \mathrm{H}_{14} \mathrm{O}_{3}$ & Feroxidin \\
7 & 9.74 & $235.0956[\mathrm{M}+\mathrm{H}]^{+}$ & 234.08921 & $\mathrm{C}_{13} \mathrm{H}_{14} \mathrm{O}_{4}$ & 2-Methoxyanofinic acid \\
8 & 9.82 & $339.1582[\mathrm{M}+\mathrm{H}]^{+}$ & 338.15181 & $\mathrm{C}_{21} \mathrm{H}_{22} \mathrm{O}_{4}$ & Licochalcone A \\
9 & 10.12 & $233.1889[\mathrm{M}+\mathrm{H}]^{+}$ & 232.18272 & $\mathrm{C}_{16} \mathrm{H}_{24} \mathrm{O}$ & Candidate mass $\mathrm{C}_{16} \mathrm{H}_{24} \mathrm{O}$ \\
10 & 10.18 & $301.2154[\mathrm{M}+\mathrm{H}]^{+}$ & 300.20893 & $\mathrm{C}_{20} \mathrm{H}_{28} \mathrm{O}_{2}$ & Sugiol \\
11 & 10.34 & $477.3655[\mathrm{M}+\mathrm{Na}]^{+}$ & 454.37706 & $\mathrm{C}_{26} \mathrm{H}_{50} \mathrm{~N}_{2} \mathrm{O}_{4}$ & Candidate mass $\mathrm{C}_{26} \mathrm{H}_{50} \mathrm{~N}_{2} \mathrm{O}_{4}$ \\
12 & 10.48 & $505.3973[\mathrm{M}+\mathrm{Na}]^{+}$ & 482.40836 & $\mathrm{C}_{28} \mathrm{H}_{54} \mathrm{~N}_{2} \mathrm{O}_{4}$ & Candidate mass $\mathrm{C}_{28} \mathrm{H}_{54} \mathrm{~N}_{2} \mathrm{O}_{4}$ \\
13 & 10.82 & $573.3923[\mathrm{M}+\mathrm{Na}]^{+}$ & 550.40221 & $\mathrm{C}_{36} \mathrm{H}_{54} \mathrm{O}_{4}$ & Adhyperforin \\
14 & 11.32 & $429.3721[\mathrm{M}+\mathrm{H}]^{+}$ & 428.36543 & $\mathrm{C}_{29} \mathrm{H}_{48} \mathrm{O}_{2}$ & Stigmastan-3,6-dione \\
15 & 11.43 & $413.3771[\mathrm{M}+\mathrm{H}]^{+}$ & 412.37052 & $\mathrm{C}_{29} \mathrm{H}_{48} \mathrm{O}$ & Spinasterol \\
16 & 11.50 & $639.4974[\mathrm{M}+\mathrm{Na}]^{+}$ & 616.50668 & $\mathrm{C}_{39} \mathrm{H}_{68} \mathrm{O}_{5}$ & Candidate mass $\mathrm{C}_{39} \mathrm{H}_{68} \mathrm{O}_{5}$ \\
17 & 11.69 & $615.4965[\mathrm{M}+\mathrm{H}]^{+}$ & 614.49103 & $\mathrm{C}_{39} \mathrm{H}_{66} \mathrm{O}_{5}$ & Candidate mass $\mathrm{C}_{39} \mathrm{H}_{66} \mathrm{O}_{5}$ \\
\hline
\end{tabular}


<smiles>CC(=O)CC(O)C(C)=O</smiles>

3-Hydroxy-2,5-hexadione<smiles>COc1cc(/C=C/C=O)ccc1O</smiles>

tran-Ferulaldehyde<smiles>COC(=O)c1ccc(OC)c(O)c1</smiles>

Methyl-3-hydroxy-4-methoxybenzoate<smiles>O=C1C=C[C@]2(O)CCO[C@H]2C1</smiles>

Rengyolone<smiles>C=CC(C)(C)c1cc(/C=C/C(=O)c2ccc(O)cc2)c(O)cc1OC</smiles>

Licochalcone A<smiles>C[C@H]1C[C@H](O)Cc2cc(O)cc(O)c21</smiles>

Feroxidin<smiles>COc1cc2c(cc1C(=O)O)C=CC(C)(C)O2</smiles>

2-Methoxyanofinic acid<smiles>CC(C)c1cc2c(cc1O)[C@@]1(C)CCCC(C)[C@H]1CC2=O</smiles>

Sugiol

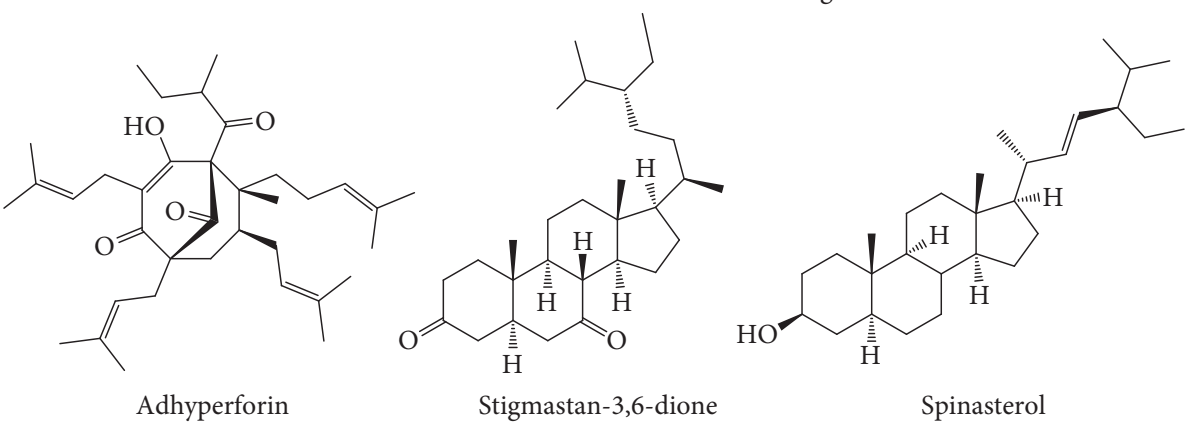

FIgURE 6: Structure molecule of the chemical constituents of fraction B.

compounds in fraction $\mathrm{B}$, such as rengyolone [22], licochalcone A [23], sugiol [24, 25], and spinasterol [26], have been known to have activity against cancer cells. For fraction E, thymine [27], aschantin [28], lirioresinol B dimethyl ether [29], and others have potency as anticancer, as well.

For the compound licocalchone $\mathrm{A}$, the antiproliferative and apoptotic effects of MDA-MB-231 cancer cells have been investigated. Licocalchone A provides an antiproliferative activity by inducing cell cycle arrest at G0/G1 in MDA-MB-231 cells $[23,30]$. In addition, licocalchone A exhibits apoptotic effects in MDA-MB-231 cells by inducing cleaved caspase- 3 and caspase- 8 and promoting caspase- 3 activity in MDA-MB-231 cells through partial extrinsic signal pathway activation [23,30]. It also provides an antimetastatic effect, although our finding resulted in the antimetastatic effect by wound-healing methods which was not better than fraction E. Licochalcone A decreased phosphorylation of AKT, JNK, $p 38$, and NF- $\kappa$ B. It also enhances the expressions of E-cadherin and reduces vimentin levels in MDA-MB-231 cells. This activity was in a concentration-dependent manner [23]. Thus, licochalcone A is a chemical component in fraction $\mathrm{B}$, influencing the cytotoxic effect on MDA-MB-231 cells.

Fraction E demonstrated the antimetastasis effect through antimigration activity compared to other fractions because of the lirioresinol $\mathrm{B}$ dimethyl ether (LBDE) contained in fraction E. LBDE provides antimetastasis and bone microenvironment by inhibiting parathyroid hormone-related protein (PTHrP), matrix metallopeptidase 9 (MMP-9), and cathepsin $\mathrm{K}$ activities in breast cancer cells and resorption of osteoclastic bone [29]. LBDE belongs to tertrahydrofurofuran lignans that prevent metastasis by suppressing TGF- $\beta$ that induced cancer cell viability, migration, invasion, and PTHrP expression. PTHrP has a role in cancer progression and metastasis through a vicious cycle [29]. Fraction E also provides cytotoxic activity, although it was not efficacious than fraction B. This activity might be affected by NF- $\kappa$ B signaling pathway inhibition [31]. 

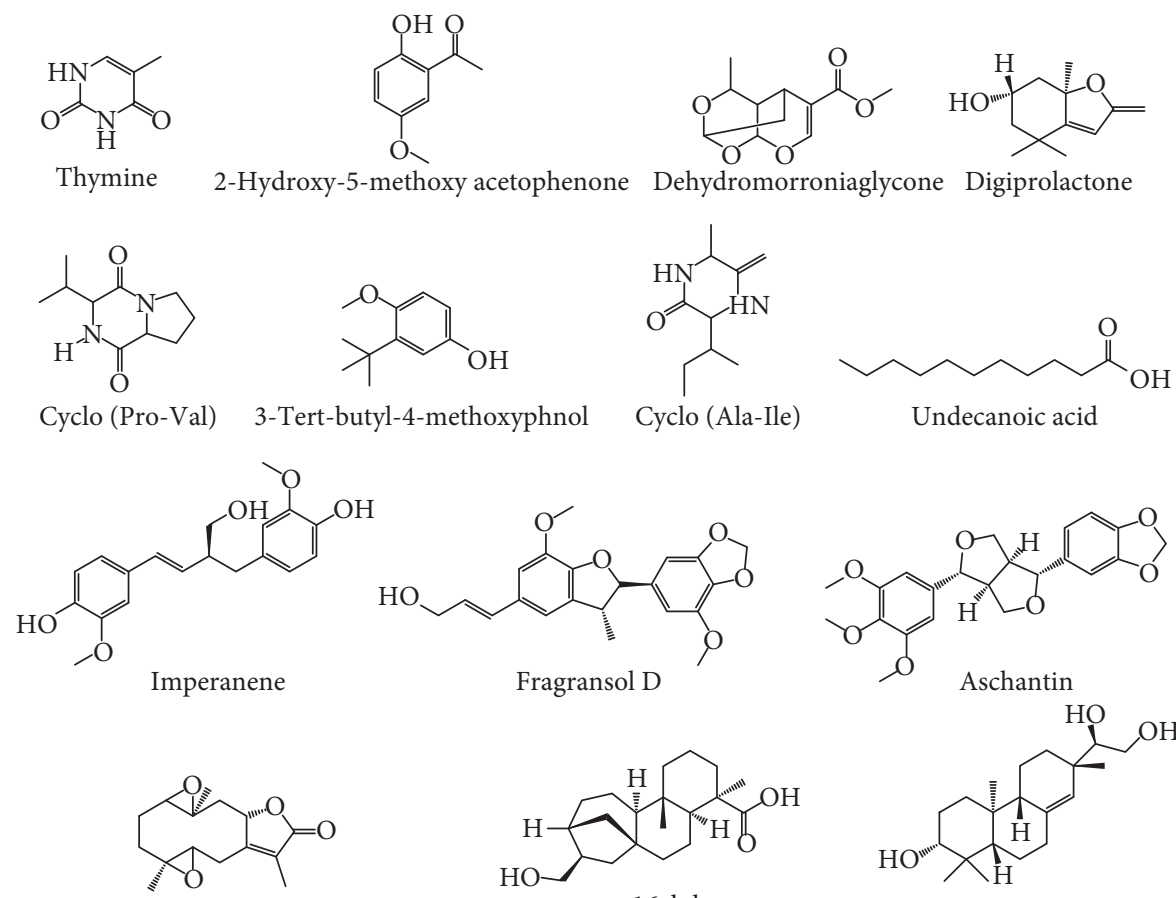

1,10:4,5-Diepoxy-germacren-12,8-olide

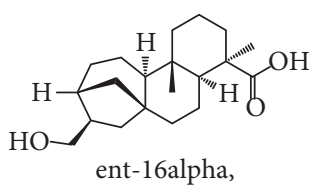

17-Hydroxy-19-kauranoic acid<smiles>CC1C(O)CCC2(C)C34CCC(CO)(CO)CC3CCC12CC4</smiles>

Darutigenol<smiles>CCOC(=O)c1cc(OCC)ccc1O</smiles>

Ethyl-5-ethoxy-2-hydroxy benzoate Neociwujiaphenol<smiles>COC1=CC2CC3COCC3C(c3cc(OC)c(O)c(OC)c3)C2C(OC)=C1O</smiles>

ol<smiles>C=C1CCC2C(C)CCCC2(C)C1CCC(C=O)CCO</smiles>

(E)-Labda8 (17)<smiles>[Y19]c1cc(O)c(C[C@@H](CCC(C)(C)O)C(=C)C)c2oc3c(O)c4cc(O)ccc4c(O)c3c(=O)c12</smiles>

Figure 7: Structure molecule of the chemical constituents of fraction E.

TABLE 2: Chemical composition of fraction E.

\begin{tabular}{lccccc}
\hline No. & Observed Rt $(\mathrm{min})$ & Observed $(\mathrm{m} / \mathrm{z})[(+)$-ESI $]$ & Neutral mass $(\mathrm{Da})$ & Formula & Compound name \\
\hline 1 & 1.38 & $113.0332[\mathrm{M}+\mathrm{H}]^{+}$ & 112.02728 & $\mathrm{C}_{4} \mathrm{H}_{4} \mathrm{~N}_{2} \mathrm{O}_{2}$ & Candidate mass $\mathrm{C}_{4} \mathrm{H}_{4} \mathrm{~N}_{2} \mathrm{O}_{2}$ \\
2 & 1.86 & $127.0489[\mathrm{M}+\mathrm{H}]^{+}$ & 126.04293 & $\mathrm{C}_{5} \mathrm{H}_{6} \mathrm{~N}_{2} \mathrm{O}_{2}$ & Thymine \\
3 & 4.16 & $237.1113[\mathrm{M}+\mathrm{H}]^{+}$ & 236.10486 & $\mathrm{C}_{13} \mathrm{H}_{16} \mathrm{O}_{4}$ & Candidate mass $\mathrm{C}_{13} \mathrm{H}_{16} \mathrm{O}_{4}$ \\
4 & 4.22 & $167.0692[\mathrm{M}+\mathrm{H}]^{+}$ & 166.06299 & $\mathrm{C}_{9} \mathrm{H}_{10} \mathrm{O}_{3}$ & 2-Hydroxy-5-methoxy acetophenone \\
5 & 4.37 & $227.0905[\mathrm{M}+\mathrm{H}]^{+}$ & 226.08412 & $\mathrm{C}_{11} \mathrm{H}_{14} \mathrm{O}_{5}$ & Dehydromorroniaglycone \\
6 & 4.47 & $219.1005[\mathrm{M}+\mathrm{Na}]^{+}$ & 196.10994 & $\mathrm{C}_{11} \mathrm{H}_{16} \mathrm{O}_{3}$ & Digiprolactone \\
7 & 4.56 & $197.1273[\mathrm{M}+\mathrm{H}]^{+}$ & 196.12118 & $\mathrm{C}_{10} \mathrm{H}_{16} \mathrm{~N}_{2} \mathrm{O}_{2}$ & Cyclo(Pro-Val) \\
8 & 4.75 & $203.1055[\mathrm{M}+\mathrm{Na}]^{+}$ & 180.11503 & $\mathrm{C}_{11} \mathrm{H}_{16} \mathrm{O}_{2}$ & 3-Tert-butyl-4-methoxyphenol \\
9 & 4.92 & $185.1273[\mathrm{M}+\mathrm{H}]^{+}$ & 184.12118 & $\mathrm{C}_{9} \mathrm{H}_{16} \mathrm{~N}_{2} \mathrm{O}_{2}$ & Cyclo(Ala-Ile) \\
10 & 5.05 & $209.1525[\mathrm{M}+\mathrm{Na}]^{+}$ & 186.16198 & $\mathrm{C}_{11} \mathrm{H}_{22} \mathrm{O}_{2}$ & Undecanoic acid \\
11 & 5.17 & $353.1375[\mathrm{M}+\mathrm{Na}]^{+}$ & 330.14672 & $\mathrm{C}_{19} \mathrm{H}_{22} \mathrm{O}_{5}$ & Imperanene \\
12 & 5.65 & $371.1480[\mathrm{M}+\mathrm{H}]^{+}$ & 370.14164 & $\mathrm{C}_{21} \mathrm{H}_{22} \mathrm{O}_{6}$ & Fragransol D \\
\hline
\end{tabular}


TABle 2: Continued.

\begin{tabular}{|c|c|c|c|c|c|}
\hline No. & Observed Rt (min) & Observed $(\mathrm{m} / \mathrm{z})[(+)-\mathrm{ESI}]$ & Neutral mass $(\mathrm{Da})$ & Formula & Compound name \\
\hline 13 & 5.78 & $401.1584[\mathrm{M}+\mathrm{H}]^{+}$ & 400.15220 & $\mathrm{C}_{22} \mathrm{H}_{24} \mathrm{O}_{7}$ & Aschantin \\
\hline 14 & 6.19 & $265.1426[\mathrm{M}+\mathrm{H}]^{+}$ & 264.13616 & $\mathrm{C}_{15} \mathrm{H}_{20} \mathrm{O}_{4}$ & $1,10: 4,5$-diepoxy-germacren-12,8-olide \\
\hline 15 & 6.29 & $321.2415[\mathrm{M}+\mathrm{H}]^{+}$ & 320.23514 & $\mathrm{C}_{20} \mathrm{H}_{32} \mathrm{O}_{3}$ & ent-16 $\alpha, 17$-Hydroxy-19-kauranoic acid \\
\hline 16 & 6.49 & $323.2573[\mathrm{M}+\mathrm{H}]^{+}$ & 322.25079 & $\mathrm{C}_{20} \mathrm{H}_{34} \mathrm{O}_{3}$ & Darutigenol \\
\hline 17 & 6.81 & $597.1969[\mathrm{M}+\mathrm{H}]^{+}$ & 596.18938 & $\mathrm{C}_{31} \mathrm{H}_{32} \mathrm{O}_{12}$ & Candidate mass $\mathrm{C}_{31} \mathrm{H}_{32} \mathrm{O}_{12}$ \\
\hline 18 & 7.00 & $211.0955[\mathrm{M}+\mathrm{H}]^{+}$ & 210.08921 & $\mathrm{C}_{11} \mathrm{H}_{14} \mathrm{O}_{4}$ & Ethyl-5-ethoxy-2-hydroxy benzoate \\
\hline 19 & 7.30 & $443.1072[\mathrm{M}+\mathrm{H}]^{+}$ & 442.09938 & $\mathrm{C}_{33} \mathrm{H}_{14} \mathrm{O}_{2}$ & Candidate mass $\mathrm{C}_{33} \mathrm{H}_{14} \mathrm{O}_{2}$ \\
\hline 20 & 7.37 & $425.1582[\mathrm{M}+\mathrm{Na}]^{+}$ & 402.16785 & $\mathrm{C}_{22} \mathrm{H}_{26} \mathrm{O}_{7}$ & Neociwujiaphenol \\
\hline 21 & 7.97 & $621.2307[\mathrm{M}+\mathrm{Na}]^{+}$ & 598.24141 & $\mathrm{C}_{32} \mathrm{H}_{38} \mathrm{O}_{11}$ & Candidate mass $\mathrm{C}_{32} \mathrm{H}_{38} \mathrm{O}_{11}$ \\
\hline 22 & 8.30 & $303.2311[\mathrm{M}+\mathrm{H}]^{+}$ & 302.22458 & $\mathrm{C}_{20} \mathrm{H}_{30} \mathrm{O}_{2}$ & (E)-Labda-8(17),12-diene-15,16-dial \\
\hline 23 & 8.69 & $209.1161[\mathrm{M}+\mathrm{H}]^{+}$ & 208.10994 & $\mathrm{C}_{12} \mathrm{H}_{16} \mathrm{O}_{3}$ & Elemicin \\
\hline 24 & 9.04 & $537.2112[\mathrm{M}+\mathrm{H}]^{+}$ & 536.20463 & $\mathrm{C}_{30} \mathrm{H}_{32} \mathrm{O}_{9}$ & Isolappaol A \\
\hline 25 & 9.16 & $447.2015[\mathrm{M}+\mathrm{H}]^{+}$ & 446.19407 & $\mathrm{C}_{24} \mathrm{H}_{30} \mathrm{O}_{8}$ & Lirioresinol B dimethyl ether \\
\hline 26 & 9.28 & $457.1844[\mathrm{M}+\mathrm{H}]^{+}$ & 456.17842 & $\mathrm{C}_{25} \mathrm{H}_{28} \mathrm{O}_{8}$ & Kushenol G \\
\hline
\end{tabular}

\section{Conclusions}

Our finding suggests that fraction B of E. alba rhizome extract has an antiproliferative effect on the MDA-MB-231 cell lines. On the other hand, fraction $\mathrm{E}$ displayed better activity in a migration cell assay. Fraction B that suppresses the tumor growth with licocalchone A might provide this activity, but not as efficacious as cisplatin in blocking tumor growth. On the contrary, fraction $\mathrm{E}$ is still not more efficacious than cisplatin in suppressing tumor growth but has similar activity in blocking metastasis. The lirioresinol B dimethyl ether (LBDE) contained in this fraction $\mathrm{E}$ might provide this antimetastasis activity.

\section{Data Availability}

The raw data used to support the findings of this study are accessible from the corresponding author.

\section{Conflicts of Interest}

The authors declare no conflicts of interest.

\section{Acknowledgments}

This research publication was supported by Academic Leadership Grant (ALG), Universitas Padjadjaran.

\section{References}

[1] H. Sung, J. Ferlay, R. L. Siegel et al., "Global cancer statistics 2020: GLOBOCAN estimates of incidence and mortality worldwide for 36 cancers in 185 countries," CA: A Cancer Journal for Clinicians, vol. 71, no. 3, pp. 209-249, 2021.

[2] Y.-S. Sun, Z. Zhao, Z.-N. Yang et al., "Risk factors and preventions of breast cancer," International Journal of Biological Sciences, vol. 13, no. 11, pp. 1387-1397, 2017.

[3] J. Mehanna, F. G. Haddad, R. Eid, M. Lambertini, and H. R. Kourie, "Triple-negative breast cancer: current perspective on the evolving therapeutic landscape," International Journal of Women's Health, vol. 11, pp. 431-437, 2019.

[4] T. C. De Rujiter, J. Veeck, and J. P. J. de Hoon, "Characteristics of triple-negative breast cancer," Journal of Cancer Research and Clinical Oncology, vol. 137, no. 2, pp. 183-192, 2011.
[5] M. L. Plasilova, B. Hayse, B. K. Killelea, N. R. Horowitz, A. B. Chagpar, and D. R. Lannin, "Features of triple-negative breast cancer: analysis of 38,813 cases from the national cancer database," Medicine, vol. 95, no. 35, p. e4614, 2016.

[6] H. Gonçalves, M. R. Guerra, J. R. Duarte Cintra, V. A. Fayer, I. V. Brum, and M. T. Bustamante Teixeira, "Survival study of triple-negative and non-triple-negative breast cancer in a Brazilian cohort," Clinical Medicine Insights: Oncology, vol. 12, Article ID 1179554918790563, 2018.

[7] G. N. Sharma, R. Dave, and J. Sanadya, "Various types and management of breast cancer: an overview," Journal of Advanced Pharmaceutical Technology \& Research, vol. 1, no. 2, pp. 109-126, 2010.

[8] Y.-W. Chin, K. Yoon, and J. Kim, "Cytotoxic anticancer candidates from terrestrial plants," Anti-Cancer Agents in Medicinal Chemistry, vol. 9, no. 8, pp. 913-942, 2009.

[9] V. Devadass, P. Raman, and D. Gayathri, "Anti-cancer compounds from terrestrial and marine resources-in silico and experimental studies," Current Computer Aided Drug Design, vol. 16, 2020.

[10] A. Fristiohady, R. Andriani, and R. B. Ramadhani, "Penentuan kadar hambat minimum ekstrak etanol rimpang Etlingera alba (blume) A. D. Poulsen terhadap bakteri penyebab diare cronobacter muytjensii dan pengembangannya dalam sediaan granul," Jurnal Sains dan Teknologi Pangan, vol. 5, no. 5, pp. 3380-3391, 2020.

[11] R. Hamsidi, W. Wahyuni, I. Sahidin, and E. Apriyani, "Suppression of proinflammatory cytokines by Etlingera alba (A.D.) poulsen rhizome extract and its antibacterial properties," Advances in Pharmacological and Pharmaceutical Sciences, vol. 2021, Article ID 5570073, 6 pages, 2021.

[12] A. Ghasemzadeh, H. Z. E. Jaafar, A. Rahmat, and S. Ashkani, "Secondary metabolites constituents and antioxidant, anticancer and antibacterial activities of Etlingera elatior (Jack) R.M.Sm grown in different locations of Malaysia," BMC Complementary and Alternative Medicine, vol. 15, no. 1, p. 335, 2015.

[13] F. Sabli, M. Mohamed, A. Rahmat, and M. F. A. Bakar, "Cytotoxic properties of selected Etlingera spp. and zingiber spp. (zingiberaceae) endemic to borneo," Pertanika Journal of Tropical Agricultural Science, vol. 35, no. 3, pp. 663-671, 2012.

[14] P. Iawsipo, E. Srisook, M. Ponglikitmongkol, T. Somwang, and O. Singaed, "Cytotoxic effects of Etlingera pavieana rhizome on various cancer cells and identification of a potential anti-tumor component," Journal of Food Biochemistry, vol. 42, no. 4, Article ID e12540, 2018. 
[15] K. J. Chavez, S. V. Garimella, and S. Lipkowitz, "Triple negative breast cancer cell lines: one tool in the search for better treatment of triple negative breast cancer," Breast Disease, vol. 32, no. 1-2, pp. 35-48, 2011.

[16] F. Mohammed, F. Rashid-Doubell, S. Taha, S. Cassidy, and S. Fredericks, "Effects of curcumin complexes on MDA-MB-231 breast cancer cell proliferation," International Journal of Oncology, vol. 57, no. 2, pp. 445-455, 2020.

[17] M. Byambaragchaa, J. de la Cruz, S. H. Yang, and S.-G. Hwang, "Anti-metastatic potential of ethanol extract of saussurea involucrata against hepatic cancer in vitro," Asian Pacific Journal of Cancer Prevention, vol. 14, no. 9, pp. 5397-5402, 2013.

[18] K. Muniandy, S. Gothai, and W. S. Tan, "In vitro wound healing potential of stem extract of Alternanthera sessilis," Evidence Based Complementary and Alternative Medicine, vol. 2018, Article ID 3142073, 13 pages, 2018.

[19] L. F. Calandrini de Azevedo, T. A. Alves Ferreira, K. M. Melo et al., "Aqueous ethanol extract of Libidibia ferrea (Mart. Ex Tul) L.P. Queiroz (juca) exhibits antioxidant and migrationinhibiting activity in human gastric adenocarcinoma (ACP02) cells," PLoS One, vol. 15, no. 1, Article ID e0226979, 2020.

[20] H. Wang, S. Guo, S.-J. Kim et al., "Cisplatin prevents breast cancer metastasis through blocking early EMT and retards cancer growth together with paclitaxel," Theranostics, vol. 11, no. 5, pp. 2442-2459, 2021.

[21] M. A. Farag, D. M. Rasheed, M. Kropf, and A. G. Heiss, "Metabolite profiling in trigonella seeds via UPLC-MS and GC-MS analyzed using multivariate data analyses," Analytical and Bioanalytical Chemistry, vol. 408, no. 28, pp. 8065-8078, 2016.

[22] J. H. Kim and C. H. Lee, "Rengyolone inhibits apoptosis via etoposide-induced caspase downregulation," Journal of Microbiology and Biotechnology, vol. 19, no. 3, pp. 286-290, 2009.

[23] T. H. Kang, J. H. Seo, H. Oh, G. Yoon, J. I. Chae, and J. H. Shim, "Licochalcone A suppresses specificity protein 1 as a novel target in human breast cancer cells," Journal of Cellular Biochemistry, vol. 118, no. 12, pp. 4652-4663, 2017.

[24] S.-N. Jung, D.-S. Shin, H.-N. Kim et al., "Sugiol inhibits STAT3 activity via regulation of transketolase and ROSmediated ERK activation in DU145 prostate carcinoma cells," Biochemical Pharmacology, vol. 97, no. 1, pp. 38-50, 2015.

[25] Y. Wang, L.-Y. Shi, W.-H. Qi, J. Yang, and Y. Qi, "Anticancer activity of sugiol against ovarian cancer cell line SKOV3 involves mitochondrial apoptosis, cell cycle arrest and blocking of the RAF/MEK/ERK signalling pathway," Archives of Medical Science, vol. 16, no. 2, pp. 428-435, 2020.

[26] G.-C. Jeon, M.-S. Park, D.-Y. Yoon, C.-H. Shin, H.-S. Sin, and S.-J. Um, "Antitumor activity of spinasterol isolated from Pueraria roots," Experimental \& Molecular Medicine, vol. 37, no. 2, pp. 111-120, 2005.

[27] W.-B. Mo, C.-H. Su, J.-Y. Huang, J. Liu, Z.-F. Chen, and K.-G. Cheng, "Synthesis of acyl oleanolic acid-uracil conjugates and their anti-tumor activity," Chemistry Central Journal, vol. 10, no. 1, 2016.

[28] C. J. Lee, J. H. Jang, J. Y. Lee et al., “Aschantin targeting on the kinase domain of mammalian target of rapamycin suppresses epidermal growth factor-induced neoplastic cell transformation," Carcinogenesis, vol. 36, no. 10, pp. 1223-1234, 2015.

[29] A. Y. Jun, H.-J. Kim, K.-K. Park et al., "Tetrahydrofurofurantype lignans inhibit breast cancer-mediated bone destruction by blocking the vicious cycle between cancer cells, osteoblasts and osteoclasts," Investigational New Drugs, vol. 32, no. 1, pp. 1-13, 2014.
[30] W.-C. Huang, H.-H. Su, L.-W. Fang, S.-J. Wu, and C.-J. Liou, "Licochalcone A inhibits cellular motility by suppressing E-cadherin and mapk signaling in breast cancer," Cells, vol. 8, no. 3, p. 218, 2019.

[31] A. Shehzad, S. Rehmat, S. Ul-Islam et al., "Lirioresinol B dimethyl ether inhibits NF- $\kappa \mathrm{B}$ and COX-2 and activates $\mathrm{I} \kappa \mathrm{B} \alpha$ expression in CCl4-induced hepatic fibrosis," BMC Complementary Medicine and Therapies, vol. 20, no. 1, p. 49, 2020. 